Žarko Pavić ${ }^{1}$

Independent University, Banja Luka,

Bosnia and Herzegovina
SCIENTIFIC REVIEW ARTICLE doi:10.5937/ekonomika1901085P

Received: August, 15, 2018 Accepted: October, 05, 2018

\title{
HEALTH MANAGEMENT EDUCATION E-LEARNNING MODEL
}

\begin{abstract}
E-Learning is a generic name for many different tools and methods to apply Information and Communication Technology to learning. As it is a fast evolving area of expertise, we provide below the most significant aspects to be considered as possible approaches or options when we were starting to design an educational system in the Health Management fields using e-learning methods. Experience shows that guidelines for the development of e-learning systems have both advantages and disadvantages. One important disadvantage is the fact that it is difficult to generalize guidelines for e-learning systems because educational situations often very considerably. Despite all the disadvantages, guidelines can be used effectively in this area. The aim of our E-learning Health Management Study, which is carried out at our University, is to establish a cooperative and mobile e-learning system in the area of the Health Management and Health Policy Development. In the MBA course of the Health Management we designed and developed the E-learning Health Management Education System. The project was also clarify how guidelines for e-learning systems can be used successfully in different clinical entities using as a parameters: screening, prevention, diagnosis, treatment, follow-up and education.
\end{abstract}

Keywords: education, e-learning, health management.

JEL classification:I15,I18, I25

\section{ЕДУКАТИВНИ МОДЕЛ ОБРАЗОВАЊА У ОБЛАСТИ ЗДРАВСТВЕНОГ МЕНАЏМЕНТА}

\begin{abstract}
Апстракт
Е-учење је генерички назив за многе различите алате и методе за примену информационих и комуникационих технологија у учење. Како се брзо развијају област експертизе, пружамо испод најзначајнијих аспеката који се могу сматрати могућим приступима или опщијама када смо почели да дизајнирамо образовни систем у областима управљања здрављем коришћењем метода е-учења. Искуство показује да смернице за развој система е-учења имају и предности и недостатке. Један важаних недостатак је чињеница да је тешко генерализовати смернице за системе е-учена јер су образовне ситуације често веома значајне. Упркос свим недостацима, смернице се могу
\end{abstract}

\footnotetext{
${ }^{1}$ zarkopavic@yahoo.com
} 
ефикасно користити у овој области. Циљ наше студије о управљањуздрављем е-учена, који се спроводи на нашем универзитету, јесте успостављање система кооперативног и мобилног е-учења у области управљања здрављем и здравственим политикама. На МБА курсу здравственог менаимента дизајнирали смо и развили систем Е-учене за здравствени менацмент. Пројекат је такође разјаснио како се смернице за системе е-учења могу успешно користити у различитим клиничким субјектима који користе као параметре: посматрање, превенцију, дијагнозу, лечење, праћење и едукацију.

Кључне речи: образовање, е-учење, здравствени менаимент.

\section{Introduction}

E-Learning as understood today is "any electronic tool, method and system used to design, develop, deliver, assess and manage more or less methodically and systematically the overall teaching and learning process“. The educational use of any specific or generic software application working on a Computer Hard-drive, or from a USB Key, from a CD-Rom or a DVD can be considered as e-Learning. But in its most common sense, e-Learning is connection to the Internet or any other telecommunication network, as Teleconferencing, Videoconferencing, Wide Area Network, Local Area Network, VoIP or Mobile telephone. E-Learning covers school, university, vocational and professional education and training as well as lifelong learning, as a formal or informal process.In fact, e-Learning is "Information and Communication Technology Application to Learning", and it can include all possible modalities: Face-to-face learning in the traditional classroom setting, Distance Learning and any mix of the two called "Blended Learning". But it can also be called "Computer-Supported Collaborative Learning", "Technology Enhanced Learning" or many other possible denominations.E-Learning is today promoting fast and evolving science and technology research and development areas in many universities, international and European scientific or development projects and national or international organizations devoted to standards specifications definition worldwide. From these important activities new educational technologies and methodologies are emerging and providing opportunities that can be possible approaches or options in educational projects. As digital technology changed the face of global transparency in the different fields like strategic policy, financing reform, health communications, it is also modifying educational practice and context. We will try to present briefly below what main perspectives have been opened, especially regarding outputs and outcomes of our Project named "Serbian School of Health Management e-Learning System". In Conclusion we will explain our remarks about some very clear e-learning Advantages, but also Dilemmas.

\section{Learning Management System and Virtual Learning Environment}

Learning Management Systems are now ubiquitous in most universities as well as in any kind of school around the world to manage many administrative, communication, educational and statistical aspects. Such systems implemented through web applications 
related to databases are facilitating many different management activities, as for instance student registration and fees payment, information and documents dissemination; educational resources distribution, tracking of student activities in discussion forums, individual or group assignments; results to assessment as well as individual, group or global statistical reports. Each of these functions can be activated or not. On top of such generic options many features are available as plug-ins or optional functions.Learning Management Systems can be downloaded free of charge on the Internet, or acquired from commercial companies with different kind of free or proprietary licenses. Moodle and Blackboard are the most prominent options in each category. According to the selected option it can also be freely installed and maintained on a server relying on permanent technical staff or relying on external commercial services (Rosenberg, 2001, Melton, 2002, Wong et al, 2010).

\section{Collaborative Learning}

Scientific research in educational psychology carried out since the last century is concluding that learning is achieved better by individuals through tutored activities in collaborative groups. Combinations of different face-to-face and virtual learning environments are looking to be more efficient and attractive than the traditional academic course model. Many possible software solutions and options are available to design and provide such collaborative environments to carry out individual or group activities implementing socioconstructivists approaches to teaching and learning. Web-based applications such as Wikis and Blogs are very appropriate(Childs et al, 2005,Garrison, 2011).

\section{Free Open Source Software and Open Educational Resources}

Two different major models are in competition today for software development and dissemination. The "Proprietary" model relies on the traditional commercial perspective where the product is sold as ready to be installed, developed internally protected by a "Proprietary" license. This kind of license prevents the user from "opening" the source code of the software to see how it works and make modifications for any reason. It also prohibits copying and redistributing this software as it is, or modified. Copying is in fact very easy and costs nothing, as the product is immaterial. Many such pirated copies of proprietary software are used in education, but this is illegal.

At the opposite there is the "Free Open Source Software" model that is developed collaboratively through peer review, by individual volunteers and/or companies making the source code freely available to all on the Internet. It is protected by an "open" license that guarantees the free (as in freedom of) access to the software source code to everybody; and the free use of the software, (learning, modifying and redistributing), but under the same license. This allows any individual or organization to get free software, to use it and adapt it freely to one's use and redistribute it eventually. Which also means that such software being reviewed by so many persons is evolving and improving faster than proprietary means.

Based on the same assumption and it is the same for textbooks contents and educational resources. If it is developed and published as "Open Educational Resources", not only it is free and open to be modified and adapted, but also it can improve faster and be more efficient. A huge movement has started to publish entire lists of courses and 
educational resources under "Creative Commons" licenses or other licenses, as "Open Educational Resources” in many universities worldwide (McVeigh, 2009, Garrison, 2011).

\section{Learning Design}

Based on different scientific research, efficient instructional design methods and technologies are providing today a consistent platform to design and develop sound "Units of Learning". For instance Benjamin Bloom's taxonomy of learning objectives and Robert Gagné's "nine events of instruction" are providing an efficient basis to structure learning in a coherent system (Gagné, 1995).

A Competence-based approach also presents a convincing model to define, through a needs analysis initial step, the competences to be acquired by the targeted population, using a structured model including all necessary information to design the entire learning system. In this model, competences may be divided in taxonomy with several levels, each element of competence being described in terms of performance, criteria of performance, and indicators of performance. Those indicators may be classified using Gagné's Taxonomy of learning outcomes, or other suitable models. The Cheetham \& Chivers model is currently very popular (.Cheetham \& Chivers, 2005).

Having achieved such competence definition, all necessary information to design the learning will be available: i) from the performance definition it is possible to derive directly the learning objectives; ii) from the performance criteria we get the different topics to be addressed and possible contents; iii) from the indicators of performance we get all necessary information to design the assessment tools.

\section{Learning Styles and Usability}

Learning is achieved by individuals through specific psychological typical settings called "learning styles", and also through declared or implicit preferences. There are different models to identify and manage learning styles - David Kolb's Learning-Style Inventory is one of the most famous psychological approaches.

Learning preferences or Media preferences deal with preferred personal learning strategies / heuristics and if the student learns better with speech, text, graphics, video or any multimedia combination. These considerations can impact on the design of the Units of Learning, not only in their didactical structure but also in the ergonomic dimension of the media design and functional environment that is called "usability" (Melis et al, 2003).

E-Learning media and environments are based on computer interaction, and their efficiency is directly related to the usability of the design. So usability is efficiency in the intuitive learning of the interface's commands (also called "Learnability"), and efficiency in the learning achieved by the student. Units of Learning designed with poor usability create more difficulties to the learner not related with the topic to be learned. The learner may be distracted from learning by having to learn how to use the contents or the system. That can have a negative impact on course completion rates and post-test scores. As a conclusion, usability of learning media and environments must be tested with a sample of targeted users (Eyler \& Giles, 1999). 


\section{Learning Technology Standards}

From an economical perspective, in order to be able to share, reuse and adapt learning resources in the same system or in any other, different international consortia have specified a set of standard metadata. Produced by an instructional designer, a teacher or a learner, a "Learning Object" can be compliant to such standards when "packeted" with specific tools as Reload or eXe.

\section{LifeLong Learning}

In our globalized knowledge-based economy, e-Learning is providing new opportunities for adults to cope with competences they need to adapt to necessary evolutions in their practices, or to access new responsibilities. Lifelong Learning is a flexible concept for educational and training institutions, projects, enterprises etc. to offer any kind of training, competence development service and qualification to anyone: young not yet employed, worker in activity, unemployed, all through his or her professional life.

The characteristics of anywhere-anytime networked collaborative learning based on competence definition and IMS Learning Design standards are very attractive in this perspective. Important research and development European projects are currently ongoing - TENCompetence is one of the most important. "TENCompetence is a 4-year EU-funded Integrated IST-TEL project that will develop a technical and organisational infrastructure for lifelong competence development. The infrastructure will use opensource, standards-based, sustainable and innovative technology. The TENCompetence infrastructure will support the creation and management of networks of individuals, teams and organisations in Europe who are actively involved in the various occupations and domains of knowledge. These learning networks will support the lifelong competency development of the participants from the basic levels of proficiency up to the highest levels of excellence. The network consists of learners, educational institutes, libraries, publishers, domain specific vendors, employers, associations, and all others who deliver services or products in the specific field(Hege et al, 2007)

\section{Challenges in e-Learning and educational innovation adoption}

Implementing an e-Learning project in an educational institution may be challenging. It is proposing different methods for people with comfortable strategies, attitudes, methods, tools and habits already in place. Changing to something new that they don't know will not be easy for them. It will be necessary to promote the solutions selected, to convince and motivate all targeted users and deciders to be part of the project. Training of trainers and specific training resources and activities will be necessary to train all intended users to use efficiently the system. It is risky to implement a system that is not yet negotiated and prepared with the intended users. Resistance to change must be managed cautiously, because "the inherent nature of organisations is to be conservativeand protect themselves from constant change" (Rossett, 2002, McGorry,2003). 


\section{Project Results}

\section{E-Learning System for the School of Health Management}

We proposed and established that the e-Learning system for the School of Health Management should include four major Sections (see: "Mapping of theSchool of Health Management e-Learning System"):

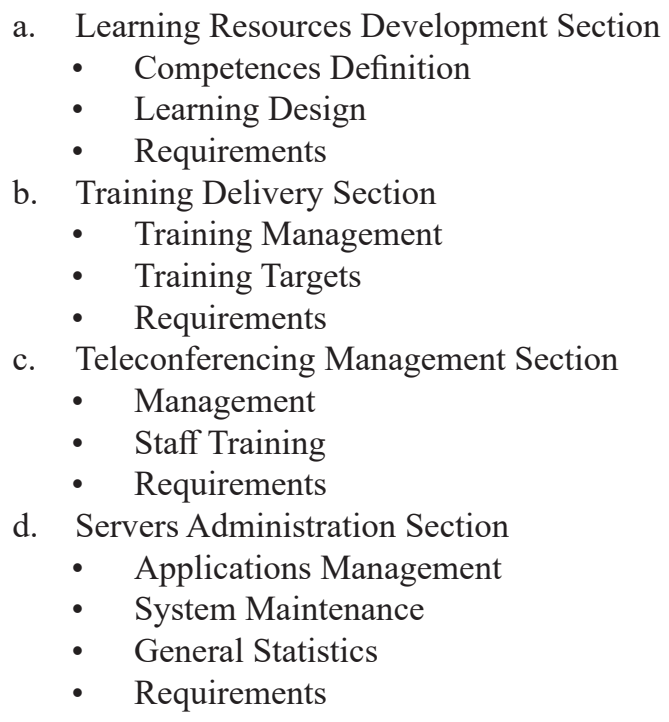

Generally, learning is a central topic within many of the psychology experts, and its problems have provided the occasion for hundreds of experimental studies. The science of learning remains in a state of flux, in part because we have not yet reached agreement upon the most appropriate concepts to use in stating our problems and in interpreting our data. Our Project "Health Management Education - New Approaches and Possibilities" included also developing of the School of Health Management e-Learning System follow the process of the accreditation in our high-education system. Health Management e-Learning System gave to our standard medical education completely new health communication possibilities represents an attempt to provide in one place the key points input-parameters like a new medical theories in praxis and new aspects of the different clinical guidelines and/ordisease protocols. The aim was to see theory in relation to our e-learning experimental model represented in the Project. The topic chosen was in each clinical case one actively studied by adherents to the theory, which could be judged both by its provocativeness in suggesting e-learning experiments, and by its success in dealing systematically with the data which emerge from such experiments. 
Methodology topics were:

- Setting the Task or Question to be addressed

- Selecting the Medical and Non-Medical Experts

- Choosing and Preparing the Scientific Evidence

- Structuring the Interactions

- Methods of Synthesis Individual Judgements

- Priorities for Future Research

Project implementation strategy consisted of the next topics:

- Establishing of the Focus and Multidisciplinary Expert Group

- Preparation of the e-Learning Project Budgeting

- Holding Meetings and Permanent Group Communication

- Use of the Specifically Developed Computer Templates and Cards

- Audit and Feedback of Results

Guideline Algorithm Management was involving in our E-learning system the next parameters for each investigated clinical entities:

- Screening

- Prevention

- Diagnosis

- Treatment

- Follow-up

- Education 


\section{Mapping of the School of Health Management E-Learning Model}

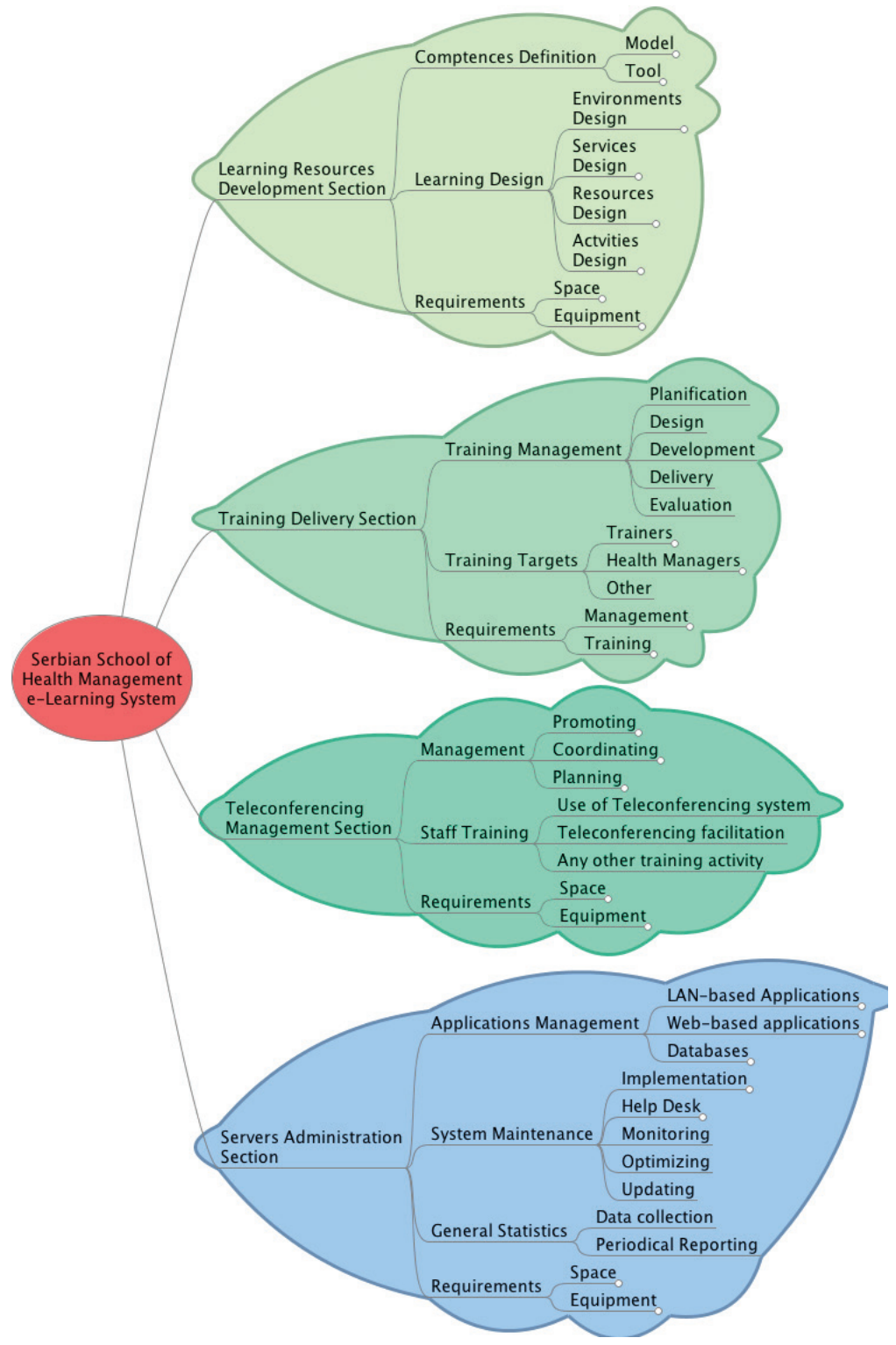

\section{Conclusions}

In conclusion we can suggest,as an output and outcome of our Project, that implementation of the e-learning Health Management System together with classical Education System is not so easy because of the many experienced established Education Standards and Norms which were the mayor obstacles for better understanding and 
application, not only inHealth Medical Education,but also in Medical Praxis.All 4 Sections represented in the Project'se-Learning Application Proposal/Learning Resources Development, Training Delivery, Teleconferencing Management and Servers Administration Sections/ were completely involved in our MBA Health Management Courses and, for some experimental clinical entities like Diabetes Mellitus, Hypertension and Rehabilitation, in the clinical investigation. Results was very satisfied on the scientific level, but not enough applicable in the clinical praxis. Methodology Topics, Project Implementation Strategy and Guideline Algorithm Management with 6 parameters /screening, prevention, diagnosis, treatment, follow-up and education/ signs, for the future, very creative, comfortable, up to date and fast withstrong multidisciplinary effectiveness and efficacy. During the application of our Project Proposal Goals we found finally the next very clear e-learning Advantages and Dilemmas:

1. Advantages using Health Management E-learning Model

- Better understanding through joint discussions using all 4 e-learning Sections in the School of the Health Management,

- Better and faster Multidisciplinary Connection between Theory and Praxis,

- $\quad$ Flexibility to join discussions in the Trainings Delivery Section threaded discussion areas at any hour,

- Health Management Instructors and MBA students both report e-Learning fosters more interaction among students and instructors than in large lecture courses,

- Develops knowledge of the Internet and Computers Skills that will help learners throughout their Health Management Careers Development.

2. Dilemmas regarding Health Management E-learning Model

- Without the routine structures of a traditional class, students may get lost or confused about MBA Health Management Course activities and deadlines,

- Health Management Instructor may not always be available when MBA students are studying or need help,

- Slow Internet connections or older computers may make accessing MBA Health Management Course materials frustrating,

- Hands-on or lab work is difficult to simulate in a virtual place like in Clinics or in the University Classroom.

\section{References}

Cheetham, B, Chivers, J (2005) "Professions, Competence and Informal Learning", ISBN-10: 1843764083.

Childs,S, Blenkinsopp, E, Hall, A (2005) "Effective e-learning for health professionals and students - barriers and their solutions. A systematic review of the literaturefindings from the HeXL project", Wiley Online LibraryHealth Information \& Libraries Journal Volume 22, Issue Supplement s2, 20-32. 
Eyler, J, Giles Jr, DE (1999) “Where's the Learning in Service-Learning?”, JosseyBass Higher and Adult Education Series.

Gagné, R (1995) “The Conditions of Learning”, Principles of Instructional Design.

Garrison, DR (2011) "E-learning in the 21st century: A framework for research and practice", Textbook, London.

Hege, I, Ropp, V, Adler, M, Radon, K (2007) "Experiences with different integration strategies of case-based e-learning”, Vol. 29, No. 8, 791-797.

McGorry, S. Y (2003): »Measuring quality in online programs«. The Internet and Higher Education, vol. 6, no. 2, 159-177.

McVeigh, H (2009) "Factors influencing the utilisation of e-learning in postregistration nursing students",Nurse Education Today, Volume 29,Issue 1, 91-99.

Melis, E., Weber, M., Andres, E. (2003) »Lessons for (pedagogic) usability of eLearning system «. Proceedings of World Conference on ElLearning in Corporate, Government, Healthcare, and Higher Education (str. 281-284). Chesapeake, VA, USA: AACE.

Melton, R.F. (2002): »Planning and developing open and distance learning: A quality assurance approach«. London/New York: RoutledgeFalmer.

Rosenberg, MJ (2001) "E-learning: Strategies for delivering knowledge in the digital age", E-learning Handbook, London.

Rosset, A (2002) "Best practices, strategies, and case studies for an emerging field", The ASTD e-learning Handbook, NewYork.

Simonović, Z., Simić, V., \& Todorov, J. (2014). Sistem zdravstvenog, penzionog i invalidskog osiguranja poljoprivrednika u Srbiji. Ekonomika, 60(1), 140-147.

Wong, G, Greenhalgh, T, Pawson, R (2010)“'Internet-based medical education: a realist review of what works, for whom and in what circumstances",BMC Medical Education. 